All citizens can play an important role in the optimisation of resources and care, as health active agents, agents of civil protection first responders and potential victims of a mass casualty incident. Mass casualty incident is a MCI scenario film that can be utilised as a pedagogical tool for individual and social awareness for violence and injury prevention and control.

\title{
1012 MASS CASUALTY INCIDENT
}

H Marques* Correspondence tos Hospital S Joo, Universidade Catlica Portugesa, Rua de Entre Campos n 141, E5, 1 Dr Tras 4410-180 S. Felix da Marinha Vila Nova de Gaia Oporto 4410-180, Portugal

10.1136/ip.2010.029215.1012 